\title{
Geoengineering super low carbon cows: food and the corporate carbon economy in a low carbon world
}

\author{
Jim Ormond ${ }^{1}$ (D)
}

Received: 12 September 2018 / Accepted: 14 June 2020 /Published online: 13 July 2020

(C) The Author(s) 2020

\begin{abstract}
The tangible progress to address climatic change remains painfully slow. As a result, practices to deliberately manipulate the Earth's carbon and energy cycles to counteract climate change have gained traction and they are increasingly incorporated into mainstream debate. This paper examines one of the less documented examples of climate geoengineering, namely the creation of 'super low carbon cows'. Driven by the public's desire for a low carbon pint of milk or beef burger, I show how a combination of bioengineering, technological fixes and management practices have resulted in, and are informing, everyday changes to the way in which animals are bred, cared for and eaten - and in turn, how it affects the food that we consume. Thus, the role of the cow within the Anthropocene now extends from meat machine and sentient being to climate change saviour. I seek to show that super low carbon cows represent part of a wider climate 'responsibilisation' in which business interests and corporate storytelling are governing and enacting everyday mundane practices of climate engineering as part of the corporate carbon economy. Yet, as with other climate 'fixes', this paper shows that the super low carbon cow provides, at best, an imperfect correction. Critical gaps in the evidence of the efficiency of the solutions being advanced remain whilst manipulating an animal to be more climate friendly evokes unease when considering the wider sustainability and ethical impacts. Perhaps most critically, reliance on climate engineering to provide cheap and easy ways to control our climate fails to question, far less address, the ever-increasing demand, production and wastage of food. It also potentially undermines the already weak political will for other essential and more radical responses to climate change. In doing so, I contrast the extensive efforts to change the everyday behaviours of a cow with the limited attempts to meaningfully challenge the everyday practices, consumption lifestyles and dietary choices of the general public.
\end{abstract}

This article is part of the Special Issue on "Everyday Climate Cultures: Understanding the cultural politics of climate change" edited by Goodman, Doyle and Farrell

Jim Ormond

jimormond83@gmail.com

1 Department of Geography and Environmental Science, University of Reading, Reading, UK 
Keywords Climate change $\cdot$ Geoengineering $\cdot$ Carbon reduction $\cdot$ Dairy

\section{Introduction}

Despite the unprecedented scientific consensus, public awareness and political resolve to address climate change, there is limited evidence of a shift towards low carbon behaviours or structural changes to enable a low carbon economy. Instead, practices to deliberately manipulate the Earth's climate to counteract anthropogenic climate change, known as geoengineering or climate engineering, have gained traction and been increasingly incorporated into mainstream climate debates (IPCC 2014, 2018). Seen through this technocratic frame, solutions have been set out ranging from the somewhat realistic, such as fertilising trees with nitrogen to absorb more carbon (Abbas et al. 2017) or adding powdered limestone into the ocean to increase carbon sequestration (Keller et al. 2014), to the fanciful. This includes spraying sulphur particles into the atmosphere (Keith et al. 2018), sending giant mirrors into space to deflect sunlight away from the Earth (Angel 2006) or increasing the radius of the Earth's orbit around the sun (Jain 1993), thereby countering climate change and at the same time, adding 5.5 days to each year.

In this paper, I examine one of the less documented examples of climate engineering: The combination of bioengineering, technological fixes and management practices designed to reduce the greenhouse gas (GHG) emissions generated and emitted by cows. In describing the creation of what I refer to here as 'super low carbon cows', I set out four arguments. First, whilst the media revels in 'pie-in-the-sky' geoengineering solutions (e.g. Jain's orbital extension), many of which are unlikely to ever be implemented, there is a need to focus critically on the ethics, equity and efficiency of the everyday practices through which climate control is already being enacted. Here I employ the term 'everyday' to highlight that the spectacular nature of geoengineering is actually comprised of a series of mundane, everyday activities. In this case, how cows are bred, fed and cared for. In doing so, I contrast the extensive efforts to change the everyday behaviours of a cow, with the limited attempts to challenge the everyday practices, consumption models and lifestyle choices of the general public.

Second, I demonstrate that super low carbon cows represent part of a wider trend within the new carbon economy, in which responsibility for GHG emissions is being assigned to actors across corporate value chains (see also Ormond 2015; Ormond and Goodman 2015; Higgins et al. 2015). As Lohmann (2014), among others, has discussed, the solutions to solve climate change serve to responsibilise particular actors in particular ways. I refer to two practices. First, corporate commitments to reduce carbon are transferred to farmers and, in turn, their cows. This serves to extend the stewardship role and responsibility of farmers from the very local (i.e. their farms) to the global commons. It also serves to responsibilise nature itself (i.e. cows become the embodiment of carbon reduction). Second, corporate carbon measurement practices and storytelling create an optimistic narrative in which climate responsibility for the public is directed away from questioning market structures and consumption behaviours to questions of brand loyalty. In short, the corporate carbon narrative redirects the responsibility of the consumer from 'should I buy?' to 'what brand should I buy?'

The paper's third argument reflects upon the 'atmosphere of hope' (Flannery 2015) contradiction which lies at the heart of many technocratic fixes pervading discussions of environmental governance, sustainable intensification and the new carbon economy. Namely, the failure to address the root cause, or as Kiehl (2006) puts it, the proclivity 
for 'treating the symptom over the cause'. Here I show that the super low carbon cow is largely predicated upon an efficiency solution within which technological fixes and management practices enable greater production efficiencies (i.e. an increased ratio of meat or milk yield to resource input). The result is that fewer animals are required to produce the same amount of product, thus reducing the relative carbon footprint of an individual pint of milk or beef steak. Yet, as with other climate and sustainable intensification, these interventions that create and that are premised upon novel green markets provide, at best, an imperfect correction. There are critical gaps remaining in the evidence of the efficiency of the solutions being advanced. In short, manipulating an animal to be 'climate friendly' fails to account for more holistic notions of sustainability. Here I speak to the wider challenge of creating a truly sustainable food system which not only meets climate change targets but also reduces the impact on land, biodiversity, water use and pollution, whilst ensuring adequate nutrition for 10 billion people by 2050 .

Finally, and perhaps most crucially, lost in the desire to produce more nutrients - in this case, in the form of dairy and beef products - the question of whether we need to produce more nutrients remains unasked. Just as with carbon-trading policies which move carbon emissions from one place to another yet fail to actually reduce the extraction of fossil fuels (Jevnaker and Wettestad 2017), reducing the carbon footprint of a single item of food does not address the ever-increasing demand, production and wastage of food that is part and parcel of the industrial food system (Evans 2014; Carolan 2018).

This paper contends that everyday technocratic fixes such as the super low carbon cow are symbolic of a corporate carbon economy which, re-enforced by relentlessly optimistic storytelling, is increasingly controlling the narrative and direction of the transition to a low carbon society as one which can be achieved through the enhanced efficiency of production practices. Critically, this undermines the already weak political will for other essential and more radical responses to climate change. Of particular relevance is the EAT-Lancet Commission (2019) report that called for an urgent global food transformation, focusing on consumption rather than production practices. The Commission found changes in production practices may only reduce agricultural GHG emission by $10 \%$ by 2050 , whereas more radical changes to consumption practices (namely a reduction in red meat and dairy and an increase in plantbased foods) could reduce GHG emissions by up to $80 \%$.

The paper begins by briefly reviewing the climate change literature, focusing on the governance of climate engineering solutions, particularly in relation to the corporate carbon economy, a perspective often overlooked beyond the abstract spectra of private investment. Here I also consider the climate change responsibilisation landscape and how different actors are tasked and imbued with the responsibility of solving climate change. In drawing upon this literature, the paper highlights how specific everyday practices of climate engineering - within and driven by the corporate carbon economy-are responsibilising cows, determining how they are bred, how they eat and how they are cared for. I conclude by discussing the implications of the super low carbon cow, both in relation to how we 'solve' climate change within a corporate carbon economy and, more widely, the changing interaction between humanity and nature within the Anthropocene. In doing so, I outline a paradoxical premise upon which this form of geoengineering rests. Human behaviours and market structures have become the dominating driver of change and in turn, the primary cause of the degradation of our earth systems. Yet the solutions put forward to mitigate this degradation fail to challenge human behaviours or market structures but rather, they seek to further change our earth systems. 


\section{Managing carbon and climate responsibility}

Deliberate intervention in the climate system has long been discussed as one approach to deal with the effects of rising GHG concentrations. This 'climate engineering' or 'geoengineering' varies widely in design and objective. It can be thought of, as per Parson and Ernst (2013), as either managing sunlight or managing carbon. The former initiatives which target the amount of solar radiation absorbed by the Earth include placing reflective screens in space, making the Earth's surface whiter by spreading light-coloured material over the land or by increasing the reflectivity of the atmosphere by spraying particles into the stratosphere (Keith et al. 2018; Proctor et al. 2018). The latter, activities that aim to reduce atmospheric GHG concentrations, include increasing the ocean's carbon uptake by fertilising plankton, enhancing the land carbon uptake by large-scale reforestation, removing carbon dioxide chemically from the air (atmospheric scrubbing) or by storing carbon dioxide underground, e.g. in depleted oil reservoirs (Keith et al. 2018).

Both forms of geoengineering and their technocratic visions of climate change mitigation elicit extreme reactions, from creating an 'atmosphere of hope' (Flannery 2015) and being akin to performing an experimental surgery with the side effects as bad as the illness (Proctor et al. 2018) to fanciful actions undermining political efforts towards mitigating climate change (e.g. Hamilton 2013). Yet with the proposed carbon reductions consistently delayed or weakened (e.g. USA withdrawal from the Paris Agreement, the failure of COP 25 climate talks) and with global emissions continuing to rise, climate engineering has gained traction as a component of the new carbon economy. The IPCC (2018) Special Report acknowledged that limiting global warming to $1.5{ }^{\circ} \mathrm{C}$ will require the use of negative emissions technologies, referencing both carbon dioxide removal and solar radiation management.

The literature on both forms of geoengineering alludes to the role of corporations. In relation to how to manage sunlight, attention has been directed to corporate research and infrastructure support for government initiatives with Sikka (2012, p. 173) arguing that special interests, including private corporations, draw on 'discursive frames to limit, shape and mould the current debate surrounding geoengineering'. Similarly, Asayama (2015) cites concerns about the influence of financial interests when private corporations are involved in geoengineering research activities. Alternatively, activities linked to managing carbon via reforestation and mechanisms such as Clean Development Mechanism (CDM) have seen attention drawn to businesses' attempts to 'green' their corporate image through offsetting their impact (Boyd 2009; Nel 2017). May et al. (2004) discuss Peugeot's \$10 million investment to plant ten million trees in Brazil to counteract the negative image of the CO2emitting car industry. Others have discussed the conflicts of interest and the lack of governmental oversight relating to corporate-funded technologies, such as carbon capture and storage or carbon credit programmes including ocean iron seeding experiments (Dalby 2015).

However, the role of corporations in geoengineering is not only expressed in the broad, nebulous activities of private capital or establishing an environmentally friendly image. Instead, and what this paper contends, geoengineering forms a part of the new corporate carbon economy defined as the techniques, practices and strategic capacities that private actors deploy to make GHG emissions thinkable and governable in the context of existing market, regulatory and supply chain models (Boykoff et al. 2009; Boyd et al. 2011; Goodman and Boyd 2011; Freidberg 2014; Higgins et al. 2015; Ormond 2015). Specifically, via everyday practices of geoengineering - in this case, the super low carbon cow-corporate interests are actively governing and enacting particular carbon cultures, low carbon transition pathways and 
the responsibilisation of specific actors for addressing climate change. In setting out this argument, this paper contributes to the wider literature exploring climate responsibilisation. This is a field of literature which can broadly be traced to Foucault's governmentality approach in that it focuses on how climate responsibility is transferred to individual agents - through ascribing freedom and autonomy whilst simultaneously appealing to individual self-responsibility — so then the rules can be exercised remotely and indirectly (see Miller et al. 1991).

Put simply, corporate carbon ambitions result in the responsibilisation of specific actors for addressing specific carbon impacts through specific pathways. For instance, Ormond (2015) examined how - through contract requirements and measurement tools - global retailers and brands re-imagine and re-define how the GHG emissions associated with their products are allocated across the product's lifecycles and supply chains. Ormond and Goodman (2015) extended this analysis to show how the commercial corporate desires to communicate a product or service's carbon footprint has sparked complicated carbon calculative practices which enrol actors at literally every node of multi-scaled and vastly complex global supply chains.

Others have discussed how carbon reductions and offset schemes such as the CDM, Gold Standard VER (Verified Emission Reduction) and UN REDD ${ }^{1}$ serve to responsibilise local communities, often in lower income countries (e.g. Bäckstrand and Lövbrand 2006). Here researchers discuss the ethics of, and practices through which, political structures and decisionmaking procedures set up by international and corporate interests interact with, transform and responsibilise local communities (Newell and Bumpus 2012). A further dimension within this literature is the role and responsibility of the public or the consuming individuals. For instance, making small changes to everyday behaviours in order to mitigate climate - such as changing light bulbs (Slocum 2004), having meat-free days (Morris et al. 2014), eating a plant-based diet (Sexton 2018; see also Goodman et al. 2010) or avoiding food waste (Evans 2014).

The creation of super low carbon cows offers an intriguing complication to this literature, exploring the different ways that the actors are imbued with climate responsibility. Specifically, this paper considers how the cultures of climate change - enacted through the everyday ordinary actions of practising lifestyles and making livelihoods - serve to inform and responsibilise human-farm animal relationships and reconstitute animals and their materialities. Crucially, given these enactments, the cow becomes more than just an animal (Wilkie 2005), being, at one and the same time, a climate change villain and a saviour.

\section{The cow-a carbon villain or climate saviour?}

The report 'Livestock's Long Shadow' by the United Nations Food and Agricultural Organisation (Steinfeld et al. 2006) was one of the first to identify the livestock sector as a climate change 'villain'. The industry's significant impact derives from the large amounts of methane - generated as a result of the everyday digestive process in ruminants - and nitrous oxide - generated through the application of fertilisers for animal feed production-which have, respectively, a global warming potential that is 25 and 298 times higher than carbon dioxide. GHG emissions from the beef and dairy sector are particularly significant given that cows are now the most numerous mammals on the Earth (Bar-On et al. 2018). In addition, by

\footnotetext{
${ }^{1}$ The United Nations Collaborative Programme on Reducing Emissions from Deforestation and Forest Degradation in Developing Countries (REED)
} 
2050, with the human population expected to reach nearly ten billion, global milk consumption is expected to double and global meat consumption is expected to triple (FAO 2010).

The climate impact of cows has seen an increased focus on the sustainability credentials of the global meat and dairy industry, recently titled 'Big Meat'. The recent report entitled 'Big meat and dairy's supersized climate footprint' found that the world's largest five meat and dairy corp Grain and IATP 2018orations are now responsible for more annual GHG emissions than Exxon, Shell or BP (), whilst the universal healthy reference diet as set out by the EAT-Lancet Commission (2019) recommends no or a low quantity of red meat.

The scrutiny on the livestock industry has led to and necessitated a series of high-profile climate change visions and carbon reduction targets by both the public sector and private businesses. The Innovation Centre for U.S. Dairy has set the goal of reducing methane emissions from dairy cattle by $25 \%$ by 2020 including by implementing the Cow of the Future project. ${ }^{2}$ The UK dairy industry-which represents approximately $2 \%$ of the UK's total emissions - has set a 20-30\% GHG emission reduction target by 2030 whilst the National Farmers' Union in the UK have set the goal of net zero GHG emissions across the whole of the UK agriculture sector by 2040. The Australian red meat industry's CN30 strategy has set a similar target to be carbon neutral by 2030 . Fonterra, a New Zealand-based multinational dairy company, and Friesland Campina, a European dairy producer, have both set the target of climate neutral growth by 2030 , whilst US meat company Tyson has set the target to reduce GHG emissions by $30 \%$ by 2030 .

Given the governance structure of the modern livestock industry, and with the majority of carbon emissions occurring as the result of everyday 'on-farm' activities such as feed production, methane generated during digestion, and manure decomposition, the majority of these targets are being framed to be achieved on-farm. For instance, in setting its ambition to be carbon neutral by 2050, dairy manufacturer Danone (2018) identified that $57 \%$ of its carbon emissions arose from its farms and that this 'requires Danone to works with farmers on low-carbon practices'. Dairy producer Arla aims to achieve net zero emissions (from their current levels of 25-30 million tonnes $\mathrm{CO} 2 \mathrm{e}$ per year) through a $30 \%$ reduction of emissions in their own sites, a $30 \%$ reduction in GHG intensity from milk production, with the remaining reductions achieved through carbon sequestration or offsetting (Arla 2019).

Corporate carbon commitments are, thus, being translated and shifted to individual farms as part of the creation of wider corporate-agriculture governance structures and market spaces in which regulation is articulated via direct retailer contracts, exclusive supplier groups and procurement guidelines (Higgins et al. 2015; Freidberg 2018). As examined in the remainder of this paper, these carbon reductions are enacted through a variety of everyday mundane production practices which disaggregate the cow as a material animal into its component parts, namely how it breeds, feeds and reproduces. The result is that through climate engineering, corporate interests are - via a combination of bioengineering, technological fixes and management practices - creating a new animal that is more desirable from a climate change point of view.

\footnotetext{
${ }^{2}$ The Cow of the Future project was established by the Innovation Center for US Dairy as part of the goal of reducing enteric methane emissions from dairy cattle by $25 \%$ by 2020 . The primary objective was to identify and prioritise existing and future technologies and practices to reduce enteric methane emissions (Knapp et al. 2011)
} 


\section{Methodology}

The material presented here is derived from a wider research project into the governance, practices and politics of product carbon footprinting (Ormond 2015). Whereas existing studies into product carbon footprinting focused on technical discussions and debates, this research examined the on-theground practices by which it has been implemented. Between 2011 and 2015, interviews were conducted with over 100 stakeholders central to the development and implementation of product carbon footprinting. The stakeholders included key decision-makers, from over 15 countries, who represented national governments, non-governmental organisations, standards institutions, industry associations and global and national corporations. The interviews were conducted in person and by telephone and followed a semi-structured format designed to generate evidence about ongoing processes of carbon footprinting. This research has been supplemented with further in-depth evidence reviews and an analysis of the corporate carbon practices, measurement and reporting over the past 5 years.

Of particular relevance to this article is the insight relating to the production and consumption of dairy and beef. This sample of participants ( $n=$ approximately 35$)$ included representatives from farmers and farming industry associations, processors, packaging companies, retailers, consumer representatives and agricultural intermediaries and carbon measurement consultants. By interviewing these stakeholders, emphasis was placed on understanding the practices by which carbon was understood and managed by different actors in different geographical sites and different social contexts.

\subsection{Breeding super low carbon cows}

Breeding cows for human requirements is not new. Indeed, whilst the techniques may have changed, the goals of eighteenth century pioneers such as Tomkins, Bakewell and Collins have remained largely consistent: identify, select and breed 'improved animals' that gain weight faster, mature sooner and grow larger. Selective breeding remains remarkably successful with improvements in animal management and genetic selection resulting in a $400 \%$ increase in milk yield over the past 60 years (Capper et al. 2009). Technological advances also now permit cows to be bred to generate fewer GHG emissions, either by breeding for efficiency (where cows produce more milk or beef for less carbon) or via explicit genomic selection (cows bred to generate less methane).

Selective breeding to increase yield, through enhanced feed efficiency or improved health, reproduction and longevity, has long been identified as offering the potential to reduce relative GHG emissions. Hyslop (2003) found bigger 'Continental' breeds of cattle produce fewer emissions per unit output than smaller 'British' breeds. Waghorn (2011) found animal breeding could achieve a reduction of $10-20 \%$ in methane production. Hegarty et al. (2007) demonstrated that cattle with a low residual feed intake - the difference between actual and predicted feed intake - can produce up to $28 \%$ less methane per animal. The key to this type of GHG reduction is selectively breeding animals to achieve production efficiencies (i.e. the ratio of yield to resource input), so, in effect, fewer animals are required to produce the same amount of product. However, whilst there is evidence of short-term GHG reductions, unlike selective breeding for increased milk yield, the long-term impact on carbon emissions is less clear. This is due to the complexity of selectively breeding animals for one low carbon genetic trait (e.g. higher milk yield) set against the negative long-term correlations on other GHG traits such as carcass quality, reproduction efficiency and animal health. 
A more direct, and potentially more permanent, approach to breeding a low carbon herd is to identify and breed from cows that discharge less methane due to genetic differences. Here, specific genetic traits (nutritional and physiological) are modified or replicated across species to directly lower the GHG emissions of cows (Hegarty and McEwan 2010). The potential for GHG reductions through genetic selection is illustrated by the University of Manitoba, which found a $27 \%$ variation in methane emissions between the different breeds. Other researchers have estimated that through selecting particular genotypes, methane emissions could be decreased by $10 \%$ in 10-15 years (De-Haas et al. 2011). Taken further, advances in genome-sequencing offer the potential to understand and modify the actual cellular processes responsible for methane production. For instance, the Genome Canada project uses genome sequencing to identify cows that produce fewer greenhouse gases with the goal of distributing the 'best' genes - via bull semen - to other herds across the world. These technological advances and the associated GHG reductions possibilities are, however, set within the highly politicised landscape of public opinion relating to the ethics and safety of genetic manipulation and engineering.

Given the commercial synergies between herd productivity, increased yield and reduced GHG emissions, breeding more efficient cows has become a prominent area of corporate research and activity. For instance, UK supermarket chain Morrisons is 'working with experts to establish a strong breeding model... and are on target to save $12 \%$ in feed costs and about a $20 \%$ reduction in greenhouse gas emissions by identifying the most feed efficient breeding animals' (Morrisons 2015). Research funded by the Technology Strategy Board and Morrisons has shown that 'super breeds' of cows such as the Stabliser ${ }^{3}$ produce around $15 \%$ less methane emissions (SRUC 2015). Retailers are actively promoting these super breeds to their producers. For instance, supermarket chain Asda subsidises Stabiliser semen by $50 \%$ through its BeefLink producer scheme whilst Morrisons offer their dairy producers a $£ 2$ bonus per calf to use Stabiliser semen (SCC 2013). The potential for GHG reduction via breeding is also captured in the guidance produced by the chocolate manufacturer Cadbury for their dairy farmers which states that 'On average, dairy cows each produce around $100 \mathrm{~kg}$ methane/year and this figure is not greatly affected by yield. If the yield per cow is increased and the cow numbers reduce correspondingly then the carbon footprint per litre can be significantly reduced. More milk per cow equals less methane per litre' (Cadbury 2009, p. 9).

\subsection{Feeding super low carbon cows}

The principal source of GHG emissions from the dairy sector is methane, generated as a byproduct of a cow's digestion processes. There are multiple ways in which managing what and how a cow eats can alter the fermentation processes within their rumen and, in turn, the volume of methane produced.

A key concern within low carbon feeding strategies relates to the balance between forage and concentrate diets. Research bodies including DEFRA in the UK, CSIRO in Australia and Dairy Management Inc. in the USA have explored how modifying animal feed and eating patterns can reduce methane emissions. Various studies have concluded that methane emissions can be reduced by supplementing forage, e.g. grass, with concentrate feed, e.g. grain, soy

\footnotetext{
${ }^{3}$ The Stabiliser breed is a multi-breed composite established in the 1970 s, which combines the fleshing ability, marbling and moderate size of the British breeds with the muscle, milk and growth of continental (European) breeds.
} 
and maize (Waghorn 2011). Central to this research is the 'efficiency argument' in which concentrate feeds provide nutrients in a more digestible format, which enhances animal productivity. Consequently, even if concentrate feed actually increases methane emissions per animal, due to the increase in productivity, the overall emissions per litre of milk or kilogram of beef are reduced, thereby a net reduction.

GHG emissions can also be reduced through pasture management strategies, for example continuous versus rotational grazing and the introduction of certain legumes. McCaughey et al. (1999) concluded that methane production is lower for cows grazing alfalfa-grass pastures than grass-only pastures. In New Zealand, Waghorn (2011) found emissions from animals grazing birdsfoot trefoil pasture were substantially lower than those grazing on a ryegrass white clover pasture. More recently, Kolling et al. (2018) found oregano and green tea extracts as feed additives reduce methane emissions.

Caution should, however, be expressed at the magnitude of these reductions, in particular when wider environmental impacts associated with animal feed production are factored in. Here GHG emissions generated by the production and transporting of animal feed crops potentially nullify any reductions gained later within the supply chain, with the impact of animal feed production (e.g. soya) on land use change and deforestation especially relevant (Garnett 2009). Questions also remain as to the impact of changing animal feed on the taste profile of the milk or beef. Reports of dairy products being tainted as a result of animals eating wild garlic and onions having existed since at least the nineteenth century - as cited within Tess of the D'Ubervilles (first published in 1891).

A second form of dietary management is the use of additives to reduce methane emissions by manipulating the ruminal fermentation processes. Here, fatty acids and oils extracted from plant sources are added to cattle feed. Researchers in France report incorporating vegetable oil into dairy cow feed can cut methane emissions by nearly a third (Soussana et al. 2007). Similarly, the addition of soy oil can reduce methane production by $39 \%$ (Jordan et al. 2006). Linseed oil included in the diets of lactating dairy cows reduced methane emissions by $55.8 \%$ (Martin et al. 2008). Likewise, trials of aqueous allicin extract from garlic were linked with a 94\% decrease in methane production (Newbold et al. 2010).

More recently, a range of artificial dietary supplements, growth promoters and hormone replacements have emerged with reported methane reduction properties. These include ionophores such as Bovatec ${ }^{\mathrm{TM}}$, Rumensin ${ }^{\mathrm{TM}}$ and Cattlyst ${ }^{\mathrm{TM}}$. They have antibiotic properties which increase the efficiency of feed utilisation and stimulate growth by altering the composition of an animal's ruminal microbial ecosystems, thus reducing relative methane emissions (Al-Husseini et al. 2013). For example, Monensin, a feed additive for cattle, has been shown to selectively kill the bacteria that produce methane (Arnold 2018). The use of growth proponents has fallen under intense scrutiny due to the rise of antibiotic resistance. A ban within the European Union and the USA exists on the use of antibiotics as growth promoters, although various reports suggest that these compounds are still in use (Wasley et al. 2018).

Finally, novel approaches have claimed that methane can be reduced through the medication of the cow's digestive system or via vaccines which stimulate the antibodies active in the rumen against methanogens. For instance, the Hungate 1000 research programme, published in Nature by the New Zealand AgResearch Institute, has generated a reference catalogue of 501 rumen microbial genomes, that can be used to identify vaccines and inhibitors to reduce methane emissions and improve productivity (Seshadri et al. 2018). Research has also found that removing protozoa can reduce methane emissions by $20 \%$ (Ishler 2008). The challenges 
related to this research include whether methane reduction is permanent, and, more significantly, the ethics, toxicity, safety and expense of altering the complex and evolving ecosystem of the rumen of live animals.

The potential impact of reducing GHG emissions through how, and what, cows eat has led to various initiatives from the corporate sector aimed at both feeding strategies and the use of feed additives. British Seed Houses and Asda have worked with farmers to provide a 'revolutionary new grass for dairy herds, which cut methane emissions by $20 \%$ per animal' (FoodBev 2011). The Lactalis Group, a French multinational dairy corporation in partnership with Valorex, an animal feed company, is working with their farmers to optimise the feeding of cows through changing the balance of soybeans, grass, clover, peas and beans, reportedly saving over 200 tons of carbon. Dutch dairy company, Friesland Campina, has set a target that by $2020,81.2 \%$ of dairy farmers will practice pasture grazing, rewarding farmers with a 'pasture grazing premium' of 1.50 euros per $100 \mathrm{~kg}$ milk. Stonyfield Farm, the yogurt manufacturer, has worked with farmers to change their animals' diets by including plants such as alfalfa and flaxseed to reduce methane generation. C-Lock, a South Dakota company, sells a feeding station that dispenses animals' dietary supplements such as basil to cut methane production whilst also measuring the methane content of their breath (Hammond et al. 2016).

Promoting the potential of feed additives, in 2007, Dutch company DSM announced the Clean Cow project with the goal 'to develop a feed supplement for ruminants which would reduce methane emissions by at least 30\%' (DSM 2018). Groupe Danone has added concentrations of Omega-3 into their cows' food at 600 farms in France, and found the 'animals were more robust, their digestive tract functioned better and they produced less methane.' In addition, Unilever is working with the Dairy Farmers of America to trial a feed additive that is designed to 'reduce the emission of greenhouse gases while improving animal health and welfare' (Unilever 2018).

\subsection{Caring for super low carbon cows}

The third direction through which the dairy and meat industry are attempting to reduce a cow's carbon footprint relates to everyday on-farm practices concerning how herds are managed and cared for.

This includes on-farm reproductive management practices such as improving ovulation and conception rates, breeding from animals at a younger age, increasing the productive life of breeding females and enhancing pre- and post-natal survival. Here, Garnsworthy (2004) concluded that improvements in fertility could reduce methane emissions by $24 \%$ and nitrous oxide emissions by $17 \%$, primarily by reducing the number of replacements in the herd. De Vries et al. (2008) also identified potential efficiency and methane reductions via genderselected or 'sexed' semen technology. This technology is cited as enabling producers to have more flexible selection options to breed dairy replacement heifers from the genetically superior animals in their herds, which in turn is expected to increase milk production per animal and thus reduce GHG emissions.

Management practices for low carbon cows also explore optimising the health of the cattle herds. The importance of herd health is illustrated by the World Organisation for Animal Health, which estimates that $20 \%$ of animal productivity losses are attributable to animal disease. Put simply, unhealthy animals have a lower productivity which results in higher emissions per unit of animal product. Research here has focused on limiting 'maintenance' emissions associated with non-productive periods such as by reducing lameness or illness, 
grouping animals to minimise behaviour stress or the removal of non- or less-productive animals. The objective of each of these management practices is to extend the productive lifespan of the cow, for, as Wall et al. (2008) reports, increasing the lifespan of a dairy cow from 3.02 to 3.5 lactations can reduce the methane emissions by $3 \%$. Technologies such as precision or customised feeding - which combine the genetics of the animal with feeding and grazing management - have also been cited as avenues for lowering the carbon footprint of cattle herds.

Given the relationships between herd health and productivity, carbon reduction and animal welfare, how cows are cared for represents a prominent theme within corporate carbon reduction programmes. For instance, McDonald's conducted a 3-year study into the methane emissions from cattle on 350 farms in the UK. This included creating a 'carbon calculator', accredited by the Carbon Trust, to help farmers measure and identify areas where changes to working practices can drive greater efficiencies on-farm. Cadbury's guidance booklet for their dairy farmers notes that moving forward the first age of calving from 30 months to 22 months could reduce a 100 cow herd's carbon footprint by more than 120 tonnes per year. Friesland Campina's sustainability initiatives 'Foqus planet programme' include encouraging their dairy farmers to extend their cows' lifespan by 6 months by 2020. Danone describes how they 'work with farmers on low-carbon practices such as increasing productivity and efficiency, to reduce energy use and improve manure management.' Unilever, partnering with Enka Milk in Turkey, has reported that improving the comfort, health and longevity of cows has resulted in better yields, improved milk quality and generated a $2 \%$ reduction in GHG emissions.

\section{Discussion}

The final section of this paper discusses the super low carbon cow in the context of the wider everyday relationships between society and climate and the cultures of climate change. Here, I particularly focus on the evolving relationships between humans, animals and the food that we eat as part of the transition to a low carbon society. In doing so, the paper contributes to three wider debates. First, who is governing the transition to a low carbon economy (e.g. Bulkeley and Newell 2015)? Second, how are we attempting to mitigate climate change (e.g. Freidberg 2018)? and, finally, what does this means for the relationships between humanity and nature in the Anthropocene (e.g. Willett et al. 2019)?

\subsection{Who is governing the transition to a low carbon economy?}

The super low carbon cow provides further evidence that, via commercial relationships, governance structures, measurement practices and storytelling, corporations are increasingly defining the solutions through which society attempts to address climate change. These solutions extend beyond previous discussions of the corporate carbon economy in which businesses measured their carbon footprint, embarked on voluntary actions to reduce their carbon footprint or provided corporate investment to climate research activities. Instead, this paper has shown that businesses are also actively enacting and normalising everyday climate engineering solutions across their own supply chains.

In this case, global dairy and meat producers, brand name manufacturers and retailers are directing their farmers to adopt specific carbon reduction strategies and climate engineering solutions through the use of market-based structures-e.g. financial incentives for using 
certain cattle breeds or certain feeding regimes - and through the creation of novel green markets, such as genomic sequencing services and methane-suppressing feed additives. Transferring the requirements of creating the super low carbon cow onto global supply chains represents a further dimension through which businesses exert their control over their supply chains. In short, from their position of influence and authority, corporate interests are able to responsibilise specific actors - namely farmers and their cows - to 'solve' climate change in their name.

In parallel, businesses are normalising these everyday climate engineering solutions into wider policy fora and public discourse. For instance, commenting on their engagement with the New Zealand Ministry for the Environment to develop the NZ Low Emission Roadmap, Fonterra's Chief Operating Officer explained 'New Zealand is one of the world's most emissions-efficient dairy producers. We will make the most of this position by investing in breakthrough technologies such as methane vaccines and inhibitors, low-emission feeds, and genetics that produce low-emissions animals, and then sharing them with the world.' In the UK, Tesco, via its Dairy Centre of Excellence, is working with the UK Technology Strategy Board to 'reassess the best way to feed calves', whilst the GHG reductions observed by Morrisons' through the promotion of the Stabiliser cattle breed are cited in a government report discussing future genomic improvements in beef cattle (DEFRA 2015). Similarly, supported by highly polished, optimistic, win-win corporate communications, business-led climate engineering solutions are shaping the prevalent public narrative. A narrative that serves to affirm, firstly, that the wider neo-liberal, business-led economic growth paradigm remains the central pillar for addressing climate change and, secondly, affirming the positive and unarguable role of individual companies in putting into practice specific climate solutions. As exemplified by corporate press releases, branding and marketing communications peppered with optimistic language such as Friesland Campina's 'Climate neutral growth', DSM's creation of the 'Clean Cow' and Danone's 'ambitious climate policy targeting becoming a climate neutral company by 2050 '.

Whilst easily dismissed as 'marketing speak', these optimistic headlines are important devices in (re-)positioning businesses from part of the problem (e.g. a significant source of GHG emissions) to an accepted and 'necessary' part of the solution. This echoes discussions and trends in other industries in which companies that have profited from the emission of GHGs subsequently seek to reposition themselves as part of the solution in order to protect their market position (for instance, as seen with the fossil fuel industry, see Matejek and Gössling 2014). In this case, the low carbon transition pathway associated with the super low carbon cow serves to protect dairy and meat against calls for more radical models of food production and consumption and systemic change. Here 'business-as-usual' policies of incremental change pervade (e.g. reduce emission intensity by 10\%) in contrast to more radical changes such as mass investment into regenerative agriculture or the promotion of plant-based proteins as a replacement for animal-based protein. ${ }^{4}$

The expansion of the corporate carbon economy into everyday climate engineering practices raises a number of important questions relating to accountability and the effectiveness of the solutions behind the super low carbon cow. Firstly, the pathways outlined by business are ultimately determined by a commercial logic based on the goal of capital accumulation, either from reduced input costs, protecting the sources of supply or commanding greater market

\footnotetext{
${ }^{4}$ An interesting dimension to this discussion is the recent investment by large meat and dairy companies into alternative-protein sources (see WEF 2019).
} 
share due to public perception of corporate responsibility. The question remains as to whether corporate ambitions around the low carbon cow will remain if they no longer conform to commercial logic. Second, given the combination of the infancy of carbon accounting methodologies, the transparency of corporate measurement practices and the desire for corporate 'good news' stories, caution should be expressed at the efficiency of the solutions and the magnitude of the potential carbon reductions. As illustrated in the earlier discussion of whether GHG reductions achieved from feeding cows concentrated feed may be nullified by the impact of producing and transporting the feed, particularly relating to land use change and deforestation.

\subsection{How are we mitigating climate change?}

As shown throughout this paper, a central pillar behind the creation of a super low carbon cow is the 'efficiency solution'. Namely, to avoid climate change, we need to create a more efficient cow that produces more milk or beef for fewer GHG emissions. Examples of the 'efficiency solution' discussed here include breeding for higher productivity, genetic selection to increase the growth rate, tailored diets to aid digestion, the use of additives to enhance feed intake and improved reproductive performance and herd health to avoid inactivity or 'maintenance' emissions.

Putting aside the previously discussed questions (and gaps in the current evidence) as to whether these solutions actually achieve long-term carbon reductions, the efficiency paradigm represents an important pathway and discourse in how we mitigate climate change. In contrast to highly visible forms of climate engineering, this solution is not designed to reflect heat e.g. sending mirrors into space or to re-absorb carbon e.g. vast reforestation projects, but, rather, is about making seemingly small changes to everyday practices (in this case on the farm) to generate fewer GHG emissions per unit of production. The hero of the efficiency story is the corporate measurement and communication metric of 'relative emission per ...' in this case, per pint of milk or per beef burger. For instance, Danish dairy manufacturer Arla has a target 'to reduce the carbon footprint per kilogram of milk from member farms by $30 \%$ by 2020 '. Friesland Campina reported 'GHG emissions on farm have decreased by $8.4 \%$ per kilo of milk'.

Empowered by the relative GHG emission metric and accompanied by polished optimistic corporate storytelling, the efficiency solution offers production-side win-win solutions that appeal to different audiences. For instance, for farmers, the win-win opportunity of more efficient cows that reduce GHG emission saves costs and improves profits, as outlined in the Cadbury Guide to Low Carbon Dairy Farming which states that 'efficient farming reduces the carbon footprint of milk production and provides better returns for your business - a 'win-win' situation where the environment benefits and you see improved economic returns' (Cadbury 2009 , p. 18). For national governments, the super low carbon cow offers a win-win solution consistent with wider neo-liberal and economic growth paradigms whilst avoiding the need for typically unpopular demand side policies changes (e.g. a meat or dairy 'sin-tax'). The desirability of the efficiency solution from a policy-perspective has been captured by the Knapp et al. (2011): 'improving livestock productivity so that less methane is emitted per unit of product is the most promising and cost-effective technique for reducing emissions in the U.S'.

Perhaps most critically, the super low carbon cow narrative offers a win-win for the consuming public. Here, the consistent flow of good news stories citing the latest efficiency 
achievements sets out a compelling vision in which climate change can be avoided through production-side market-based solutions, well before a pint of milk or beef-burger reaches their shopping basket, offering a win-win scenario in which climate change is avoided with minimal changes to the public's everyday consumption behaviours.

However, there is a flaw in the win-win logic of the efficiency solution. This flaw is the crucial difference between 'relative' and 'absolute' emissions. Whilst efficiency solutions may reduce the relative GHGs for one pint of milk or beef burger, if the total number of pints or burgers sold continues to increase, then so does the total absolute carbon footprint of the global cattle sector. As a consequence, everyday climate engineering practices based upon efficiencies may simply result in more, albeit highly efficient, cows. Consequently, optimistic news headlines citing efficiency reductions woefully fail to capture the magnitude of the scientific evidence that GHG emissions are still on an upward trajectory and that we are rapidly approaching a tipping point in the struggle to limit climate change to $2{ }^{\circ} \mathrm{C}$ (IPCC 2016).

Furthermore, corporate carbon mitigation activities based on the efficiency solution fail to challenge the wider market structures and lifestyle or dietary choices which ultimately are driving the GHG emissions associated with the dairy and meat sectors. Here a situation has arisen in which mundane everyday production practices are questioned whilst everyday consumption behaviours are overlooked, e.g. 'eating meat', 'going supersized' and 'throwing food away'. As a consequence, and mirroring wider discussions associated with the discourse of ecological modernisation (Howes 2018), the wider public is increasingly failing to ask (or be asked) the important questions relating to the low carbon pathways being taken, in particular whether low carbon consumption - namely buying more, or different, stuffreally is the best solution to avoid climate change.

\subsection{What does the low carbon cow mean for humanity, cows, nature and the Anthropocene?}

The pathway outlined by the efficiency solution leads into this paper's final discussion point: The changing attribution of responsibility for climate change from global retailers and manufacturers to farmers and ultimately cows and, more broadly, how this influences the discussion of the ethics of the Anthropocene.

The responsibilisation of the cow as a climate villain and then saviour offers a tangible example of how climate change policy has become predicated as a technocratic challenge. As described throughout this paper, a recurring implication is that the cow, as a material animal, can be disaggregated into its component parts (how it breeds, feeds and reproduces). These parts can be manipulated to create a new animal that is more desirable from a climate change point of view. Here I have shown everyday technocratic fixes ranging from artificial feed additives and rumen transplants to genetic manipulation, artificial insemination and altered gestation periods. As such, whilst breeding practices, technologies and interventions to alter the actual materiality of cows may have a long history, the application of these practices with the specific goal of avoiding climate change represents a new dimension to the ideologies of 'improving' the cow.

The reimagining and redesign of the cow as a super low carbon cow also offers an insight into the continuing shift in public perception of animal-human relations and changing visions for how the cow is used by humans for the production of nutrients. Specifically, this paper has shown that the technological changes and management practices associated with the super low carbon cow are geared towards an intensification of food production, with larger, more 
efficient and more intensively reared animals. This mirrors a wider pattern within animal management for food production which has irrevocably moved away from the 'romantic' imagery of 'wild' sentient animals freely foraging, replaced instead by the reality of selectively bred and bio-engineered animals raised on highly regulated diets formulated by distant scientists to serve their human masters as low carbon meat machines. A direction juxtaposed with the corporate storytelling practices and imagery which accompany modern food marketing (see Goodman 2009 and Goodman et al. 2012 among others for discussion of the disconnection between food production and consumption).

At a broader level, this paper has highlighted the role of food in addressing climate change in the Anthropocene. Here, an important context is provided by the EAT-Lancet Commission, which in calling for a Great Food Transformation - to achieve a sustainable and healthy diet for all-identified four key pathways. These are technological changes to food production, reductions in food loss and waste relating to production, dietary changes and behaviour changes relating to food loss at the point of consumption. These pathways span production and consumption yet the super low carbon cow focuses solely on the production dimensions. The Commission offers further stark reality here, stating that changes in food production practices will only reduce the agricultural GHG by $10 \%$ by 2050 , whereas changes in consumption practices (e.g. plant-based diets) could reduce emissions by up to $80 \%$.

\section{Conclusion}

With GHG emissions continuing to rise, climate engineering has gained increased traction as a policy tool to mitigate climate change. However, attempts to manage sunlight or carbon raise a number of considerations relating to governance, equity and efficiency. Whilst attention is beginning to be paid to high-profile examples, the same level of scrutiny needs to be paid to other forms of everyday practice that also represent climate engineering.

This paper has sought to address this gap by discussing the everyday climate engineering practices associated with the creation of the super lower carbon cow. In doing so, the paper has highlighted the variety of bioengineering, technological fixes and management practices through which climate change is being mitigated every day through the bodies of cows. This represents the latest (non-human) actor that is responsibilised as part of the new carbon economy (cf. Ormond 2015; Ormond and Goodman 2015). However, the orientation for more efficient milk or beef production provokes concerns as to whether breeding larger or more efficient cows that live longer lives and produce ever greater volumes of milk products and meat can be reconciled with the public sensibilities of 'good' welfare standards.

This offers an important direction for future research. Specifically, whilst studies have begun to consider the impact of climate change on ecosystems, biodiversity and animals (e.g. Pecl et al. 2017), attention must also be paid to the impact on animals and their materialities as we seek to mitigate climate change. Here attention also needs to be paid to the co-production roles of animals within the Anthropocene in terms of continuing to provide food, ecosystem services and landscapes whilst also acting as climate saviours. This paper has focused on the super low carbon cow, and similar patterns can be explored relating to the responsibilisation of other forms of nature as witnessed in the transition to super low carbon sheep, pigs and poultry (e.g. Bondi et al. 2015).

At the same time, the role of businesses and the corporate carbon economy in determining these pathways requires further and more critical detailed scrutiny. Importantly here, as with 
other geoengineering solutions, the efficient solutions proposed by the business interests and enforced by corporate storytelling are in danger of offering an unrealistic atmosphere of hope. This reveals the danger of the naïve reliance on corporate-led climate engineering. Here the unspoken paradox remains that human consumption behaviours, patterns and levels as well as market structures are the dominating drivers causing the degradation of our earth's systems. Yet, solutions put forward to mitigate this degradation fail to challenge human behaviours or market structures. They instead seek to further change our earth's systems. As such, on their own win-win solutions like the super low carbon cow-whilst representing relatively cheap, easy and optimistic solutions - are in danger of being woefully unsuitable solutions to mitigate climate change, which crucially could undermine the already weak political will for other solutions and innovations required to avoid the worst impacts of climate change.

Open Access This article is licensed under a Creative Commons Attribution 4.0 International License, which permits use, sharing, adaptation, distribution and reproduction in any medium or format, as long as you give appropriate credit to the original author(s) and the source, provide a link to the Creative Commons licence, and indicate if changes were made. The images or other third party material in this article are included in the article's Creative Commons licence, unless indicated otherwise in a credit line to the material. If material is not included in the article's Creative Commons licence and your intended use is not permitted by statutory regulation or exceeds the permitted use, you will need to obtain permission directly from the copyright holder. To view a copy of this licence, visit http://creativecommons.org/licenses/by/4.0/.

\section{References}

Abbas F, Hammad HM, Fahad S, Cerdà A, Bakhat HF (2017) Agroforestry: a sustainable environmental practice for carbon sequestration under the climate change scenarios - a review. Environ Sci Pollut Res 24(12): $11177-11191$

Al-Husseini W, Gondro C, Quinn K, Cafe LM, Chen Y (2013) Hormonal growth implants affect feed efficiency and expression of residual feed intake-associated genes in beef cattle. Anim.Prod.Sci. https://doi.org/10.1071 /AN12398

Angel R (2006) Feasibility of cooling the Earth with a cloud of small spacecraft near the inner Lagrange point (L1). Proc Natl Acad Sci 103(46):17184-17189

Arla (2019) Arla Foods aims for carbon net zero dairy. https://www.arla.com/company/news-and-press/2019 /pressrelease/arla-foods-aims-for-carbon-net-zero-dairy-2845602/. Accessed Dec 2019

Arnold M (2018) Be aware when feeding ionophores to cattle - an overdose may prove deadly - https://u.osu. edu/beef/2018/01/31/be-aware-when-feeding-ionophores-to-cattle-an-overdose-may-prove-deadly/. Accessed Dec 2019

Asayama S (2015) Catastrophism toward ‘opening up' or 'closing down'? Going beyond the apocalyptic future and geoengineering. Curr Sociol 63(1):89-93

Bäckstrand K, Lövbrand E (2006) Planting trees to mitigate climate change: contested discourses of ecological modernization, green governmentality and civic environmentalism. Glob Environ Polit 6(1):50-75

Bar-On YM, Phillips R, Milo R (2018) The biomass distribution on Earth. Proceedings of the National Academy of Sciences, p 201711842

Bondi G, Peruzzi E, Macci C, Masciandaro G, Pistoia A (2015) Changes in soil organic matter associated with pig rearing: influence of stocking densities and land gradient on forest soils in central Italy. Agric Ecosyst Environ 211:32-42

Boyd E (2009) Governing the Clean Development Mechanism: global rhetoric versus local realities in carbon sequestration projects. Environ Plan A 41(10):2380-2395

Boyd E, Boykoff M, Newell P (2011) The "new" carbon economy: what's new? Antipode 43(3):601-611

Boykoff MT, Bumpus A, Liverman D Randalls S (2009) Theorizing the carbon economy: introduction to the special issue. https://doi.org/10.1068/a42196

Bulkeley H, Newell P (2015) Governing climate change. Routledge, Abingdon

Cadbury (2009) Cadbury Guide to Low Carbon Dairy Farming [online]. Available at http://www.cadbury.co. uk/cadburyandchocolate/ourcommitments/environmental\%20commitments/pages/carbonReduction.aspx. Accessed 2017 
Capper JL, Cady RA, Bauman DE (2009) The environmental impact of dairy production: 1944 compared with 2007. J Anim Sci 87(6):2160-2167

Carolan M (2018) The real cost of cheap food. Routledge

Dalby S (2015) Geoengineering: the next era of geopolitics? Geogr Compass 9(4):190-201

Danone (2018) Towards carbon neutrality. Online available at https://www.danone.com/impact/planet/towardscarbon-neutrality.html. Accessed Dec 2019

DEFRA (2015) Study to model the impact of controlling endemic cattle diseases and conditions on national cattle productivity, agricultural performance and greenhouse gas emissions

de Haas Y, Windig JJ, Calus MPL, Dijkstra J, de Haan M, Bannink A and Veerkamp RF (2011) Genetic parameters for predicted methane production and potential for reducing enteric emissions through genomic selection. Journal of Dairy Science 94:6122-6134

De Vries A, Overton M, Fetrow J, Leslie K, Eicker S, Rogers G (2008) Exploring the impact of sexed semen on the structure of the dairy industry. J Dairy Sci 91(2):847-856

DSM (2018) Nourishing a growing population in a sustainable way http://www.dsm. com/corporate/science/challenges/climate-energy/methane-reduction.html. Accessed Dec 2019

Evans D (2014) Food waste: home consumption, material culture and everyday life. Bloomsbury Publishing

Food and Agriculture Organization (FAO) (2010) The future of food and agriculture: Trends and challenges

Food Bev (2011) Asda's sugar-rich grass to confront carbon cow conundrum. https://www.foodbev. com/news/asdas-sugar-rich-grass-to-confront-cow-c/. Accessed Dec 2019

Flannery T (2015) Atmosphere of hope: searching for solutions to the climate crisis. Atlantic Monthly Press, New York, pp 41

Freidberg S (2014) Footprint technopolitics. Geoforum 55:178-189

Freidberg S (2018) Assembled but unrehearsed: corporate food power and the 'dance' of supply chain sustainability. J Peasant Stud:1-18

Garnett T (2009) Livestock-related greenhouse gas emissions: impacts and options for policy makers. Environ Sci Pol 12(4):491-503

Garnsworthy PC (2004) The environmental impact of fertility in dairy cows: a modelling approach to predict methane and ammonia emissions. Anim Feed Sci Technol 112(1-4):211-223

Goodman D (2009) Place and space in alternative food networks: connecting production and consumption. In: Goodman M, Goodman D, Redclift M (eds) Consuming space: placing consumption in perspective. Ashgate, Aldershot, pp 189-211

Goodman MK, Boyd E (2011) A social life for carbon? Commodification, markets and care. Geogr J 177(2): $102-109$

Goodman M, Maye D, Holloway L (2010) Ethical foodscapes?: premises, promises and possibilities. Environ Plan A 42:1782-1796

Goodman D, DuPuis E, Goodman M (2012) Alternative food networks: knowledge, practice, and politics. Routledge, London

Grain and the Institute for Agriculture and Trade Policy (IATP) (2018) Emissions impossible: how big meat and dairy are heating up the planet, https:/www.grain.org/article/entries/5976-emissions-impossible-how-bigmeat-and-dairy-are-heating-up-the-planet. Accessed Dec 2019

Hamilton C (2013) Earthmasters: the dawn of the age of climate engineering. Yale University Press

Hammond KJ, Waghorn GC, Hegarty RS (2016) The GreenFeed system for measurement of enteric methane emission from cattle. Anim Prod Sci 56(3):181-189

Hegarty RS, Goopy JP, Herd RM, McCorkell B (2007) Cattle selected for lower residual feed intake have reduced daily methane production 1 2. J Anim Sci 85(6):1479-1486

Hegarty RS, McEwan JC (2010) Genetic opportunities to reduce enteric methane emissions from ruminant livestock. In Proc. 9th World Congress on Genetics Applied to Livestock Production, Germany

Higgins V, Dibden J, Cocklin C (2015) Private agri-food governance and greenhouse gas abatement: constructing a corporate carbon economy. Geoforum 66:75-84

Howes M (2018) Joining the dots: sustainability, climate change and ecological modernisation. In Pathways to a sustainable economy (pp. 15-24)

Hyslop J (2003) Simulating the greenhouse gas and ammonia emissions from UK suckler beef systems. Report to the Department for Environment, Food and Rural Affairs, London

IPCC (2014) Climate change 2014: synthesis report. Contribution of working groups I, II and III to the Fifth Assessment Report of the Intergovernmental Panel on Climate Change. IPCC, Geneva

Intergovernmental Panel on Climate Change (2016) Summary for policymakers of IPCC special report on global warming of $1.5^{\circ} \mathrm{C}$ approved by governments

IPCC (2018) Global warming of $1.5 \mathrm{C}$ - special report on the impacts of global warming of $1.5 \mathrm{C}$ above preindustrial levels 
Ishler V (2008) Carbon, methane emissions and the dairy cow. Penn State College of Agricultural Sciences Nutrient Management, pp.1-4

Jain PC (1993) Earth-Sun system energetics and global warming. Clim Chang 24(3):271-272

Jevnaker T, Wettestad J (2017) Ratcheting up carbon trade: the politics of reforming EU emissions trading. Glob Environ Polit 17(2):105-124

Jordan E, Lovett DK, Monahan FJ, Callan J, Flynn B, O’Mara FP (2006) Effect of refined coconut oil or copra meal on methane output, and on intake and performance of beef heifers. J Anim Sci 84:162-170

Keith DW, Holmes G, Angelo DS, Heidel K (2018) A process for capturing CO2 from the atmosphere. Joule 2(8):1573-1594

Keller DP, Feng EY, Oschlies A (2014) Potential climate engineering effectiveness and side effects during a high carbon dioxide-emission scenario. Nat Commun 5:3304

Kiehl JT (2006) Geoengineering climate change: treating the symptom over the cause? Clim Chang 77(3):227228

Knapp JR, Firkins JL, Aldrich JM, Cady RA, Hristov AN, Welch MD (2011) Cow of the future research priorities for mitigating enteric methane emissions from dairy. Innovation Center US Dairy

Kolling GJ, Stivanin SCB, Gabbi AM, Machado FS, Ferreira AL, Fischer V (2018) Performance and methane emissions in dairy cows fed oregano and green tea extracts as feed additives. J Dairy Sci 101(5):4221-4234

Lohmann L (2014) The injustices inside climate science. The Corner House

Martin C, Rouel J, Jouany JP, Doreau M, Chilliard Y (2008) Methane output and diet digestibility in response to feeding dairy cows crude linseed, extruded linseed, or linseed oil. J Anim Sci 86(10):2642-2650

McCaughey WP, Wittenberg K, Corrigan D (1999) Impact of pasture type on methane production by lactating beef cows. Can J Anim Sci 79(2):221-226

Matejek S, Gössling T (2014) Beyond legitimacy: a case study in BP's “Green Lashing”. J Bus Ethics 120(4): 571-584

May PH, Boyd E, Veiga F, Chang M (2004) Local sustainable development effects of forest carbon projects in Brazil and Bolivia: a view from the field. International Institute for Environment and Development (IIED), London

Miller P, Gordon C, Burchell G (1991) The Foucault effect: studies in governmentality. University of Chicago Press, Chicago

Morris C, Kirwan J, Lally R (2014) Less meat initiatives: an initial exploration of a diet-focused social innovation in transitions to a more sustainable regime of meat provisioning. Int J Sociol Agric Food 21(2):189-208

Morrisons (2015) Beef Improvement Group https://www.morrisons-farming.com/our-partners/beefimprovement-group/

Nel A (2017) Contested carbon: carbon forestry as a speculatively virtual, falteringly material and disputed territorial assemblage. Geoforum 81:144-152

Newell P, Bumpus A (2012) The global political ecology of the clean development mechanism. Glob Environ Polit 12(4):49-67

Newbold J, Kim EJ, Scolla N (2010) Reducing animal greenhouse gas emissions. IBERS Knowledge-based Innovation 3:9-15

Ormond J (2015) New regimes of responsibilization: practicing product carbon footprinting in the new carbon economy. Econ Geogr 91(4):425-448

Ormond J, Goodman MK (2015) A new regime of carbon counting: the practices and politics of accounting for everyday carbon through CO2e. Glob Environ Chang 34:119-131

Parson EA, Ernst LN (2013) International governance of climate engineering. Theoret Inquir Law 14(1):307-338

Pecl GT, Araújo MB, Bell JD, Blanchard J, Falconi L (2017) Biodiversity redistribution under climate change: impacts on ecosystems and human well-being. Science 355(6332)

Proctor J, Hsiang S, Burney J, Burke M, Schlenker W (2018) Estimating global agricultural effects of geoengineering using volcanic eruptions. Nature,p.1

Seshadri R, Leahy SC, Attwood GT, Teh KH, Lambie SC, Paez-Espino D (2018) Cultivation and sequencing of rumen microbiome members from the Hungate1000 Collection. Nat Biotechnol 36(4):359

Sikka T (2012) A critical discourse analysis of geoengineering advocacy. Crit Discourse Stud 9(2):163-175

Slocum R (2004) Consumer citizens and the cities for climate protection campaign. Environ Plan A 36(5):763782

Soussana JF, Allard V, Pilegaard K, Ambus P, Ammann C, Clifton-Brown J (2007) Full accounting of the greenhouse gas $(\mathrm{CO} 2, \mathrm{~N} 2 \mathrm{O}, \mathrm{CH} 4)$ budget of nine European grassland sites. Agric Ecosyst Environ 121: $121-134$

SRUC (2015) Net feed efficiency in stabiliser cattle. https://www.sruc.ac.uk/downloads/file/3113/net_feed efficiency_in_stabiliser_cattle. Accessed Dec 2019

SCC (2013) Stabliser news $\bar{h}$ ttps://issuu.com/powerfulgenie/docs/newsletterwinter2013. Accessed Dec 2019 
Sexton AE (2018) Eating for the post-Anthropocene: alternative proteins and the biopolitics of edibility. Trans Inst Br Geogr 43:586-600. https://doi.org/10.1111/tran.12253

Steinfeld H, Gerber P, Wassenaar TD, Castel V, Rosales M, Rosales M, de Haan C (2006) Livestock's long shadow: environmental issues and options. FAO

Unilever (2018) Sustainable dairy. https://www.unilever.com/sustainable-living/reducing-environmentalimpact/sustainable-sourcing/our-approach-to-sustainable-sourcing/sustainable-dairy/. Accessed Dec 2019

Waghorn GC (2011) Can livestock production be increased without increasing greenhouse gas emissions? Proc N Z Soc Anim Prod 71:156-162

Wall E, Bell MJ, Simm G (2008) Developing breeding schemes to assist mitigation. In: Livestock and Global Climate Change (Ed. by P Rowlinson, M Steele, A Nefzaoui). Proceedings, International Conference. Cambridge University Press, Cambridge, pp 44-47

Wasley A, Stockton B, Jones N, Heal A (2018) Critical antibiotics still used on US farm animals despite superbug crisis. https:/www.thebureauinvestigates.com/stories/2018-09-19/critical-antibiotics-still-used-usfarms. Accessed Dec 2019

World Economic Forum (WEF) (2019) How Big Food is responding to the alternative protein boom https:/www.weforum.org/agenda/2019/08/alternative-plant-protein-market-growth-food-industry-response/. Accessed Dec 2019

Wilkie R (2005) Sentient commodities and productive paradoxes: the ambiguous nature of human-livestock relations in Northeast Scotland. J Rural Stud 21(2):213-230

Willett W, Rockström J, Loken B, Springmann M, Lang T, Vermeulen S, Garnett T, Jonell M (2019) Food in the Anthropocene: the EAT-Lancet Commission on healthy diets from sustainable food systems. Lancet 393(10170):447-492

Publisher's note Springer Nature remains neutral with regard to jurisdictional claims in published maps and institutional affiliations. 